Weed Science 2017 65:19-30

(C) Weed Science Society of America, 2016

\title{
Herbicidal Activity of Monoterpenes Is Associated with Disruption of Microtubule Functionality and Membrane Integrity
}

\author{
David Chaimovitsh, Alona Shachter, Mohamad Abu-Abied, Baruch Rubin, Einat Sadot, \\ and Nativ Dudai*
}

\begin{abstract}
Aromatic plants and their volatile compounds affect seed germination and plant growth, and therefore hold potential for agriculture uses as plant growth regulators and bioherbicides. In the present study 17 major monoterpenes were selected, and their mechanisms of plant toxicity were elucidated using transgenic Arabidopsis thaliana at various growth stages. Microtubulin and the plant cell membrane were identified as the focal targets through which phytotoxicity and herbicidal activity acted. Variability in monoterpene mechanisms was observed. Limonene and (+)-citronellal had strong antimicrotubule efficacy, whereas citral, geraniol, $(-)$-menthone, $(+)$-carvone, and $(-)$-citronellal demonstrated moderate antimicrotubule efficacy. Pulegone, (-)-carvone, carvacrol, nerol, geranic acid, $(+) /(-)$-citronellol, and citronellic acid lacked antimicrotubule capacity. An enantioselective disruption of microtubule assembly was recorded for $(+) /(-)$-citronellal and $(+) /(-)$-carvone. The $(+)$ enatiomers were more potent than their $(-)$ counterparts. Citral, limonene, carvacrol, and pulegone were also tested for phytotoxicity and herbicidal activity. Pulegone had no detectable effect on microtubules or membranes. Citral disrupted microtubules but did not cause membrane damage. Carvacrol lacked a detectable effect on microtubules but incited membrane leakage, and limonene disrupted microtubules and membrane leakage. Therefore, only limonene was herbicidal at the tested concentrations. In planta quantification of residues revealed that citral was biotransformed into nerol and geraniol, and limonene was converted into carvacrol, which could explain its dual capacity with respect to microtubules and membrane functionality. The results obtained are an important added value to commercial efforts in selecting appropriate aromatic plants to be sources of bioherbicidal compounds for sustainable weed management with a limited potential for herbicide resistance evolution in weed populations.

Nomenclature: Arabidopsis thaliana, citral, limonene, pulegone, carvacrol.

Key words: Allelochemicals, aromatic plants, bioherbicides, microtubule, membrane leakage, mode of action, monoterpene.
\end{abstract}

Weeds are among the major causes of crop yield loss together with pests and diseases (Dayan and Duke 2014; Pimentel et al. 2005). In commercial production, weeds compete with the crop, reducing its growth rate and productivity. Hence, weed control is an essential practice to limit the negative effects on crop production (Berchielli-Robertson et al. 1990). Various approaches to alternative weed control are available, such as sanitation of plant material and seeds, use of mulch, solarization, hand weeding, heat, use of acids or soaps, etc. (Chappell et al. 2012).

\footnotetext{
DOI: $10.1614 /$ WS-D-16-00044.1

* First, second, and sixth authors: Unit of Medicinal and Aromatic Plants, ARO, Newe Ya'ar, P.O. Box 1021, Ramat Yishay 30095, Israel; first and fourth authors: R. H. Smith Institute of Plant Sciences in Agriculture, Faculty of Agriculture, Food and Environment, Hebrew University of Jerusalem, Rehovot 76100, Israel; third and fifth authors: Institute of Plant Sciences, ARO, Volcani Center, P.O. Box 6, Bet-Dagan 50250, Israel. Corresponding author's E-mail: nativdud@gmail.com
}

However, regardless of the alternatives, commercial production still relies heavily on herbicides with synthetic chemistries. These encompass $91.9 \%$ of the new active ingredients registered, whereas $8.1 \%$ are synthetic active ingredients derived from natural sources (Cantrell et al. 2012).

The intensive use of synthetic herbicides poses two major challenges in relation to public health, environmental damage (Narwal 1999), and the development of weeds resistant to the currently used chemistries (Dayan et al. 2012). Grana et al. (2012) pointed out environmental concerns, such as interruption of ecological equilibrium, negative influence on human health, and increased incidence of weeds developing resistance. Research has indicated increased risk of cancer and Parkinson's disease following exposure to herbicides (Gorrel et al. 1998; Kettles et al. 1997; Kogevinas et al. 1997); and Dayan et al. (2012) indicated that in the last $20 \mathrm{yr}$ herbicides with mechanisms of action for new target 
sites have not been commercialized, which consistently increases the risk for resistance developing in weed populations. Therefore, there is a considerable need for new chemistries with innovative mechanisms of action.

The public concern with the possible undesirable effects of synthetic herbicides on human health and the environment calls for the use of ecofriendly chemistries. Currently, only $7 \%$ of the commercialized chemistries approved by the U.S. Environmental Protection Agency (EPA) are natural bioherbicides (Cantrell et al. 2012; Dayan and Duke 2014), indicating the limited use of natural compounds as herbicides (Seiber et al. 2014). Aromatic plants have been a commercial source of bioactive compounds for many years (Christaki et al. 2012; Gerwick and Sparks 2014; Kala 2015). Compounds produced by aromatic plants, in particular essential oils and their monoterpene constituents, possess insecticidal (Isman 2000), antimicrobial (Abad 2014; Bossele and Juliani 2002), and herbicidal properties (Dudai 1999; Grana 2012, 2013a). In this sense, essential oils and their monoterpene constituents are innovative and ecofriendly chemistries that can potentially be used as bioherbicides.

Essential oils affect plant cells, causing membrane breakage and leakage of macromolecules and induction of oxidative stress by lipophilic compounds (Abrahim et al. 2003; Cox et al. 1988; Di Pasqua et al. 2007; Einhellig 1986; Lambert et al. 2001; Maffei et al. 2001; Sikkema et al. 1995; Singh et al. 2009a; Zunino and Zygadlo 2004). Monoterpenes are one of the largest and most important groups of secondary metabolites found in essential oils, and some of them are phytotoxic, making them potential bioherbicides (Abrahim et al. 2000; Dudai et al. 2000a). Monoterpenes are inhibitors of seed germination and plant growth (Abrahim et al. 2000; Dudai et al. 2000a; Einhellig and Leather 1988; Fischer 1986; Gouda et al. 2016; Grana et al. 2012; Reynolds 1987; Weidenhamer et al. 1994). Anatomical and physiological changes have been recorded in plant seedlings as a result of exposure to monoterpenes in both the vapor and aqueous phases (Dudai et al. 2000b; Einhellig and Leather 1988; Fischer 1986; Grana et al. 2013b; Koitabashi et al. 1997).

In 2010, Chaimovitsh et al. demonstrated inhibition of plant growth by citral. The mechanism underlying this inhibition involved microtubule disruption without a detectable effect on the actin cytoskeleton. Furthermore, in vivo and in vitro tests demonstrated a harmful effect of citral on cell microtubules that was dose and time dependent yet reversible. Nevertheless, under the experimental conditions used, damage to the plasma membrane was not recorded.

The study was continued in 2012 (Chaimovitsh et al. 2012) identifying, in wheat seedlings, that the mitotic microtubules were more sensitive to citral than the cortical microtubules. Citral inhibited the cell cycle and increased the frequency of wheat root cells and BY2 cells with asymmetric walls. The findings explained the observed phytotoxic effect of citral, at micromolar concentrations, in seed germination inhibition.

In a continuing effort to understand the phytotoxic and herbicidal potential of citral derivatives, the present study examined the hypothesis that the mechanism of citral derivatives and other related monoterpenes is via interference with the cortical microtubules, F-actin functioning, and membrane integrity.

\section{Materials and Methods}

Plant Material Used. Arabidopsis thaliana ecotype Col-0 was used. Seeds of Arabidopsis plants expressing the green fluorescent protein-tubulin $\alpha 6$ (GFP-TUA6) marker were kindly provided by T. Hashimoto (Ueda et al. 1999), and transgenic plants expressing the GFP-mTalin, were generated in the lab with a plasmid kindly provided by $\mathrm{N}$. Chua (Kost et al. 1998).

Volatile Compounds Used. The following 17 compounds were used in this study to examine their effect on plant tissue: citral, $(+) /(-)$-citronellal, geraniol, nerol, $(+) /(-)$-citronellol, citral dimethyl acetal, geranic acid, $(+) /(-)$-citronellic acid, limonene, menthone, $(+) /(-)$-carvone, pulegone, and carvacrol. All compounds were examined for their effect on microtubulin in Arabidopsis seedlings (Table 1). Four compounds-limonene, citral, pulegone, and carvacrol-were also tested for their effect on F-actin and membrane integrity in seedlings and for their effect on membrane leakage and phytotoxicity in mature Arabidopsis plants (Table 1). All compounds were purchased from Sigma-Aldrich, Israel.

Analysis of Microtubules, F-actin, and Membrane in Seedlings by Confocal Microscopy. In this test, all 17 compounds were examined for their effect on microtubulin, and citral, limonene, pulegone, and carvacrol were also tested for their effect on F-actin and cell membrane (Table 1). 
Table 1. Effect of 17 monoterpenes and citral derivatives on the activity of microtubulin, membrane, and F-actin in Arabidopsis seedlings and on phytotoxicity and plant biomass in mature Arabidopsis plants.

\begin{tabular}{|c|c|c|c|c|c|c|c|c|c|}
\hline \multirow[b]{2}{*}{ Compound } & \multirow[b]{2}{*}{ Monoterpene } & \multirow{2}{*}{$\begin{array}{c}\text { Citral } \\
\text { derivative }\end{array}$} & \multirow{2}{*}{$\begin{array}{c}\text { Dosage } \\
(\mu \mathrm{l} \text { per } 20 \mathrm{ml})^{\mathrm{a}}\end{array}$} & \multicolumn{3}{|c|}{ Disruptive effect in Arabidopsis seedlings ${ }^{\mathrm{b}}$} & \multicolumn{3}{|c|}{ Phytotoxicity and effect on mature Arabidopsis plants ${ }^{\mathrm{b}, \mathrm{c}}$} \\
\hline & & & & Microtubule & Membrane & F-actin & Membrane leakage & Herbicidal activity & Biomass reduction \\
\hline Limonene & * & & $\begin{array}{l}0.75 \\
1.5\end{array}$ & $\begin{array}{l}+ \\
+\end{array}$ & + & - & $\begin{array}{l}18.2 \% \text { (after } 30 \mathrm{~min} .) \\
\text { 29.2\% (after } 60 \mathrm{~min} .) \\
43.3 \% \text { (after } 30 \mathrm{~min} .) \\
\text { 49.8\% (after } 60 \mathrm{~min} .)\end{array}$ & $\begin{array}{l}+/-(\text { after } 30 \mathrm{~min}) \\
+(\text { after } 60 \mathrm{~min}) \\
+(\text { after } 15 \mathrm{~min})\end{array}$ & $16 \%$ after $60 \mathrm{~min}$ \\
\hline
\end{tabular}

(+)-Citronellal

(-)-Citronellal

Citral

(-)-Menthone

Geraniol

? (+)-Carvone

(-)-Carvone

Nerol

(-)-Citronellol

(+)-Citronellol

* $\quad 0.75$

1.5

* $\quad 0.75$

1.5

0.75

1.5

0.75

1.5

0.75

1.5

0.75

1.5

0.75

1.5

$\begin{array}{ll} & 1.5 \\ * & 0.75\end{array}$

0.75
1.5

$\begin{array}{ll} & 1.5 \\ * & 0.75\end{array}$

$*$
$* \quad 1.5$

0.75

1.5

\begin{tabular}{|c|c|c|}
\hline+ & $\mathrm{nt}$ & $\mathrm{nt}$ \\
\hline $\begin{array}{c}+ \\
+/-\end{array}$ & $\mathrm{nt}$ & $\mathrm{nt}$ \\
\hline+ & & \\
\hline$+/-$ & - & - \\
\hline+ & & \\
\hline $\begin{array}{l}+/ \\
+\end{array}$ & $\mathrm{nt}$ & $\mathrm{nt}$ \\
\hline$+/-$ & $\mathrm{nt}$ & $\mathrm{nt}$ \\
\hline - & $\mathrm{nt}$ & $\mathrm{nt}$ \\
\hline+ & & \\
\hline - & $\mathrm{nt}$ & $\mathrm{nt}$ \\
\hline - & & \\
\hline - & $\mathrm{nt}$ & $\mathrm{nt}$ \\
\hline - & & \\
\hline - & $\mathrm{nt}$ & $\mathrm{nt}$ \\
\hline - & & \\
\hline - & $\mathrm{nt}$ & $\mathrm{nt}$ \\
\hline - & & \\
\hline
\end{tabular}

$49.8 \%$ (after $60 \mathrm{~min}$.)

$\mathrm{nt}$

nt

nt

nt

nt

nt

nt

nt

Effect on mature Arabidopsis plants, ${ }^{\mathrm{b}, \mathrm{c}}$

Compound $\quad$ Monoterpene $\begin{gathered}\text { Citral } \\ \text { derivative }\end{gathered} \begin{array}{r}\text { Dosage } \\ (\mu \mathrm{L} / 20 \mathrm{~mL})\end{array}$

Disruptive effect in Arabidopsis seedlings ${ }^{\mathrm{b}}$

$\begin{array}{lll}\text { Citral di methyl acetal } & * & 0.75\end{array}$

Geranic acid

(-)-Citronellic acid

(+)-Citronellic acid

Microtubulin

Membrane

F-actin

Membrane leakage

Herbicidal activity

Biomass reduction

nt

nt

nt

nt

nt

nt

nt

nt

nt

nt

nt

nt

nt

nt

nt

nt

nt

nt

$\mathrm{nt}$

0.75

1.5

0.75

1.5

$\begin{array}{ll}- & - \\ - & -\end{array}$

$30 \%$ after $60 \mathrm{~min}$

${ }^{a}$ Low $(0.75 \mu \mathrm{l}$ per $20 \mathrm{ml})$ and high $(1.5 \mu \mathrm{l}$ per $20 \mathrm{ml})$ dosages.

${ }^{b}$ Effect: +, complete; +/-, partial; -, none; nt, not tested.

$\sim \quad{ }^{\mathrm{c}}$ Duration (min) of exposure to vapors. 
Arabidopsis seeds were sown onto Murashige and Skoog medium, incubated at $4 \mathrm{C}$ in darkness for $4 \mathrm{~d}$, and then transferred to a growth chamber at $24 \mathrm{C}$ under a photoperiod of $16 \mathrm{~h}$ light $/ 8 \mathrm{~h}$ dark. Then, five 8 -d-old seedlings, each weighing approximately $0.05 \mathrm{~g}$ (a total of $0.25 \mathrm{~g}$ of plant tissue), were transferred into sterile $20 \mathrm{ml}$ scintillation vials and exposed to $0.75 \mu \mathrm{l}$ (low dose) or $1.5 \mu \mathrm{l}$ (high dose) of each compound (Table 1) for $30 \mathrm{~min}$ at room temperature in darkness.

The applied molar dosages (high and low) of the compounds were as follows: citral: $8.79 \mathrm{M}$ and 4.39 $\mathrm{M} ;(+) /(-)$-citronellal: $8.31 \mathrm{M}$ and $4.15 \mathrm{M}$; geraniol: $8.64 \mathrm{M}$ and $4.32 \mathrm{M}$; nerol: $8.56 \mathrm{M}$ and 4.28 M; (+)/(-)-citronellol: $8.2 \mathrm{M}$ and $4.1 \mathrm{M}$, citral dimethyl acetal: $6.73 \mathrm{M}$ and $3.36 \mathrm{M}$, geranic acid: 8.64 $\mathrm{M}$ and $4.32 \mathrm{M},(+) /(-)$-citronellic acid: $8.13 \mathrm{M}$ and $4.06 \mathrm{M}$; limonene: $9.26 \mathrm{M}$ and $4.63 \mathrm{M}$; menthone: $8.7 \mathrm{M}$ and $4.15 \mathrm{M},(+) /(-)$-carvone: 9.58 $\mathrm{M}$ and $4.79 \mathrm{M}$; pulegone: $9.2 \mathrm{M}$ and $4.6 \mathrm{M}$, and carvacrol: $9.75 \mathrm{M}$ and $4.87 \mathrm{M}$.

The compounds were separately amended onto Whitman filter paper pieces $(1$ by $1 \mathrm{~cm})$ that were attached to the inner sides of the vials' caps. Each vial $(20 \mathrm{ml})$ was hermetically sealed, creating a vapor-rich headspace atmosphere. Following exposure, membranes were stained for $5 \mathrm{~min}$ with $8 \mu \mathrm{M}$ of styryl dye FM4-64 (Bolte et al. 2004) to examine membrane integrity. Microtubules and F-actin were determined by live GFP markers. An IX81/FV500 laser-scanning microscope (Olympus) with a Plan Apo $60 \times 1.00$ WLSM $\infty / 0.17$ objective was used to observe fluorescently labeled plant cells. The filter sets used for observation were $488 \mathrm{~nm}$ excitation and BA505-525 for GFP and 488 or $515 \mathrm{~nm}$ excitation and BA660 for FM4-64.

\section{Effect on Membrane Leakage and Phytotoxicity} in Mature Plants. In this experiment, limonene, citral, pulegone, and carvacrol were tested for their disruption of membrane integrity and phytotoxicity to mature plants (Table 1). Arabidopsis plantlets, at the two-leaf stage, were transplanted to $200 \mathrm{ml}$ pots with five plantlets per pot. The soil mixture used was composed of $65 \%$ peat TS-1 and 35\% vermiculite $\mathrm{N}-2$. The plantlets were grown under short-day conditions ( $10 \mathrm{~h}$ of daylight) in the greenhouse until they reached the 14-leaf stage, when they were transferred to the laboratory to be examined for membrane leakage and phytotoxicity.

In the laboratory, each pot was covered with a $500 \mathrm{ml}$ glass beaker. The tested compounds were each applied to a Whitman's filter paper that was attached to the inner side of the beaker. The plants were exposed to $18.75 \mu \mathrm{l}$ (low) or $37.5 \mu \mathrm{l}$ (high) of monoterpene vapor for $0,15,30$, and $60 \mathrm{~min}$. The dosages were equivalent to $0.75 \mu \mathrm{l}$ and $1.5 \mu \mathrm{l}$ previously used in the $20 \mathrm{ml}$ scintillation vials and were (low/high): $4.6 / 9.2 \mu \mathrm{mol}$ per $20 \mathrm{ml}$ for limonene, $4.4 / 9.2 \mu \mathrm{mol}$ per $20 \mathrm{ml}$ for citral, $4.8 / 9.7 \mu \mathrm{mol}$ per $20 \mathrm{ml}$ for carvacrol, and $4.6 / 9.3 \mu \mathrm{mol}$ per $20 \mathrm{ml}$ for pulegone. Plants to be examined for phytotoxicity and biomass were retransferred to the greenhouse and were evaluated 2 wk later.

Membrane-leakage quantification was carried out using plants that were exposed to the monoterpene vapors for $30 \mathrm{~min}$ following the protocol by Bernstein et al. (2010). Immediately after the $30 \mathrm{~min}$ exposure to the vapors, the treated plants with the roots removed were placed in sealed $50 \mathrm{ml}$ tubes containing $20 \mathrm{ml}$ double-distilled water. The tubes were shaken at $200 \mathrm{rpm}$ for $60 \mathrm{~min}$ at room temperature, and electrical conductivity (EC) was measured before and after autoclaving. Membrane leakage was expressed as the ratio between the two values, as follows: \% $\mathrm{EC}=\left[\left(\mathrm{EC}_{\mathrm{f}}-\mathrm{EC}_{\mathrm{i}}\right) /\right.$ $\left.\mathrm{EC}_{\mathrm{i}}\right] \times 100$, where $\mathrm{EC}_{\mathrm{i}}=\mathrm{EC}$ measured before autoclaving and $\mathrm{EC}_{\mathrm{f}}=\mathrm{EC}$ measured after autoclaving.

\section{In Planta Analysis of Monoterpene Concentra-} tions. Arabidopsis seedlings exposed to the various monoterpenes in vapor phase were weighed and placed in methyl-tert-butyl ether that contained $10 \mu \mathrm{g} \mathrm{ml}^{-1}$ iso-butylbenzene as an internal standard. The samples were shaken at room temperature for $24 \mathrm{~h}$ as previously described (Dudai et al. 2009; Lewinsohn et al. 1998). The extract was passed through a small column consisting of a Pasteur pipette containing anhydrous $\mathrm{Na}_{2} \mathrm{SO}_{4}$ and salicylic acid (Silicagel 60, 230-400 mesh, Merck) to dry it and to remove high-molecular-weight polar substances that could interfere with the gas chromatography (GC) analysis. The samples were analyzed using a $\mathrm{GC} /$ mass spectrometer (HP-GCD apparatus) equipped with an HP5 $(30 \mathrm{~m}, 0.25 \mathrm{~mm})$ fused silica capillary column. Helium was used as the carrier in constant-flow mode at $1 \mathrm{ml} \mathrm{min}^{-1}$. The injection temperature was $250 \mathrm{C}$, and the detector temperature was $280 \mathrm{C}$. Column conditions were: $70 \mathrm{C}$ for $2 \mathrm{~min}$ followed by a $4 \mathrm{C} \mathrm{min}^{-1}$ increase to $200 \mathrm{C}$. The components were identified by co-injection with authentic samples and by comparison with mass spectra from the computerized libraries Wiley7N and HP1600. Following extraction, the plants were dried in an oven at $80 \mathrm{C}$ for $48 \mathrm{~h}$ and weighed. 
Statistical Analysis. All trials were carried out in a completely randomized design with five replications per treatment. Data were explored with one-way analysis of variance (ANOVA) followed by mean separation with Tukey's HSD. Values are presented as mean \pm standard deviation.

\section{Results and Discussion}

Analysis of Microtubules, F-actin, and Membrane by Confocal Microscopy. Eight- day-old Arabidopsis seedlings expressing the microtubule marker GFP-TUA6 or the actin marker GFPmTalin were exposed to 10 citral derivatives and 6 monoterpenes and then stained with the membrane marker FM4-64 (Bolte et al. 2004). Table 1 summarizes the degree of microtubule-disrupting activity in Arabidopsis seedlings of the 10 citral derivatives: $(+) /(-)$-citronellal, geraniol, nerol, $(+) /(-)$-citronellol, geranic acid, $(+) /(-)$-citronellic acid, citral dimethyl acetal; and the 6 monoterpenes: limonene, $(+) /(-)$-carvone, (-)-menthone, pulegone, and carvacrol. Dosages and exposure duration were based on our previous work (Chaimovitsh et al. 2010) and were $0.75 \mu$ l (low dose) and $1.5 \mu$ (high dose) in $20 \mathrm{ml}$ scintillation vials for $30 \mathrm{~min}$. The compounds limonene, (+)-citronellal, and (+)-carvone completely disrupted plant microtubules at high and low dosages. Citral, (-)-menthone, geraniol, and (-)-citronellal disrupted microtubules completely and partially at the high and low dosages, respectively. On the other hand, (-)-carvone, nerol, $(+) /(-)$-citronellol, citral dimethyl acetal, geranic acid, $(+) /(-)$-citronellic acid, pulegone, and carvacrol did not. Of note was the enantioselective activity recorded for carvone and citronellal, where $(+)$-carvone and $(+)$-citronellal disrupted microtubules completely at the low and/or high dosages, whereas (-)-carvone had no effect on microtubules, and (-)-citronellal had a dose dependant activity (Table 1 ).

Citral, limonene, pulegone, and carvacrol were examined further for their effect on microtubules, F-actin, and membrane uniformity. Similar to citral (Chaimovitsh et al. 2010), the three monoterpenes lacked anti-F-actin activity (Table 1; Figure 1). Limonene caused breakage of the plasma membrane, whereas citral, pulegone, and carvacrol, did not (Table 1; Figure 1).
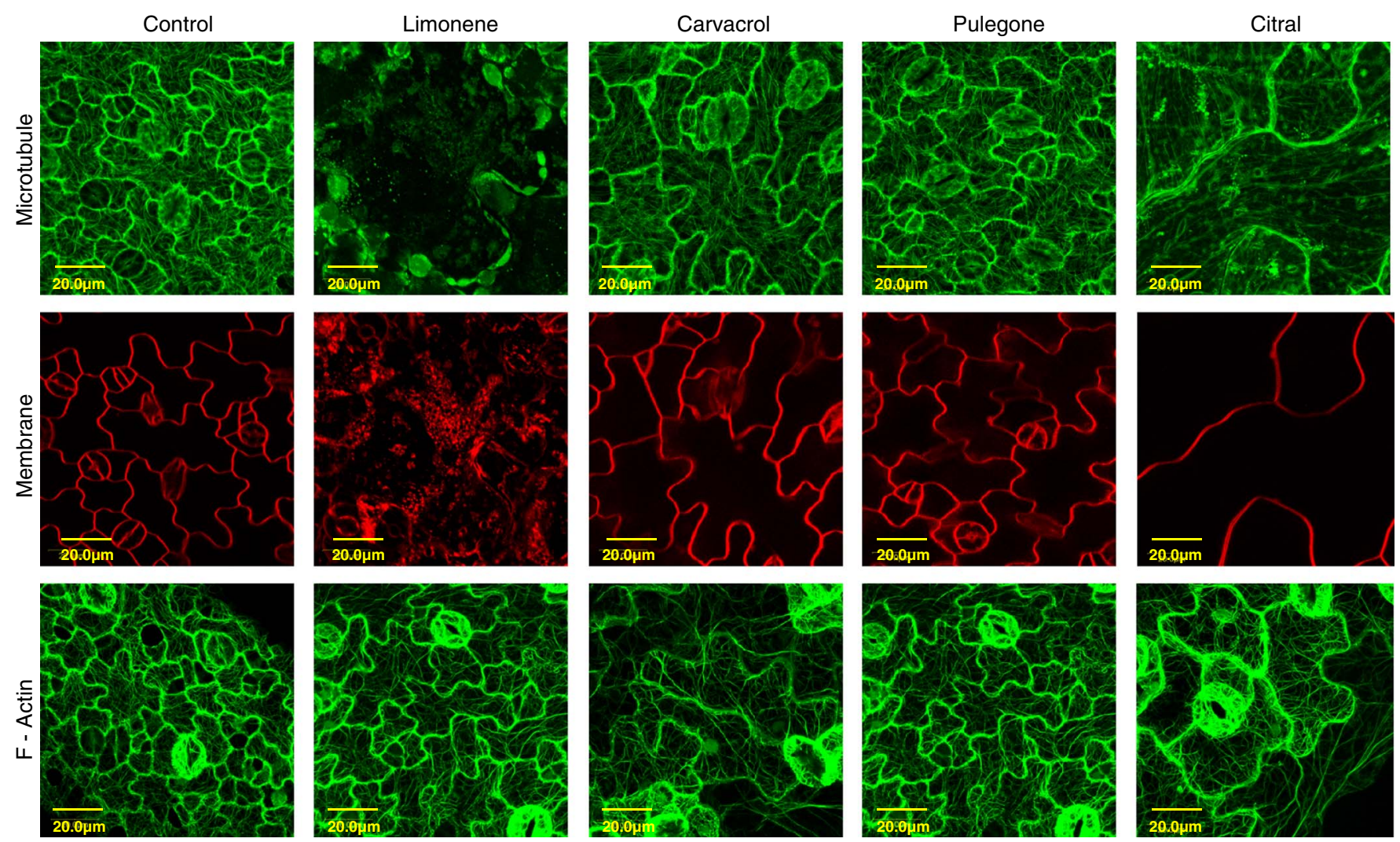

Figure 1. The effect of limonene, pulegone, and carvacrol in relation to citral on microtubules, F-actin, and the plasma membrane in Arabidopsis leaf epidermal cells. GFP-TUA6 or GFP-mTalin lines were exposed to the vapors in $20 \mathrm{ml}$ scintillation bottles for $30 \mathrm{~min}$ and then stained with FM4-64. Shown are confocal images of the abaxial leaf epidermis. 
Effect on Membrane Leakage and Phytotoxicity to Mature Plants. To compare the influence of the four monoterpenes' vapors on mature plant growth, we examined two dosages of each compound on Arabidopsis plants. Following treatment, the plants were transferred to the greenhouse, and growth was monitored for $2 \mathrm{wk}$. Only limonene had herbicidal activity (Table 1; Figure 2), initiating with phytotoxic reaction expressed as necrotic and dried leaves and eventual plant death. At the low limonene vapor concentration, a time-response effect was observed. The plants were not damaged by $15 \mathrm{~min}$ exposure and were only partially damaged after $30 \mathrm{~min}$ exposure. However, after $60 \mathrm{~min}$ exposure to limonene vapor the plants died (Table 1; Figure 2A). Exposure to the high limonene vapor concentration $(9.2 \mu \mathrm{mol}$ per $20 \mathrm{ml})$ caused severe wilting after only 15 min (Table 1; Figure 2B), indicating a strong herbicidal potential. Exposure of Arabidopsis plants to vapors of citral, carvacrol, and pulegone did not lead to significant wilting (Table 1; Figure 2C), suggesting lack of herbicidal potential at these concentrations.

The effect on biomass (Table 1; Figure 3) correlated with time and dose responses described in Figure 2. The biomass decreased from $0.29 \mathrm{~g}$ plant $^{-1}$ for the untreated control to less than $0.05 \mathrm{~g}$ plant $^{-1}$ after $60 \mathrm{~min}$ of exposure to either the low or the high concentration of limonene (Figure 3A).
Exposure to carvacrol, pulegone, or citral did not cause a significant reduction in plant biomass compared with the untreated plants at any of the time settings (Figure 3C, D).

To determine the influence of limonene, citral, carvacrol, and pulegone on the cell membrane leakage of the mature plants, we used the experimental setup described in Figure 3. Exposure of the plants to limonene at $4.6 \mu \mathrm{mol}$ per $20 \mathrm{ml}(0.75 \mu \mathrm{l}$ per $20 \mathrm{ml}$ ) led to 18.2 and $29.2 \%$ leakage after 30 and $60 \mathrm{~min}$ exposure, respectively. Exposure to limonene at $9.2 \mu \mathrm{mol}$ per $20 \mathrm{ml}(1.5 \mu \mathrm{l}$ per $20 \mathrm{ml})$ led to 43.3 and $49.8 \%$ leakage after 30 and $60 \mathrm{~min}$, respectively. Membrane leakage in control untreated plants was only $11.5 \%$ (Figure 4A). Exposure of the plants to citral, carvacrol, and pulegone vapors did not incite a significant membrane leakage (Figure $4 \mathrm{~A}, \mathrm{~B})$, except for exposure to the high dose of carvacrol $(1.5 \mu \mathrm{l}$ per $20 \mathrm{ml})$ for $60 \mathrm{~min}$, which caused $30 \%$ leakage (Figure 4B). Interestingly, the plants tolerated this apparently harmful effect, demonstrating a normal appearance after the treatment (Figure 2C).

In Planta Analysis of Monoterpene Concentrations. Monoterpene residues were quantified in Arabidopsis plants using the experimental setup described in Figure 2. Treated plants were extracted
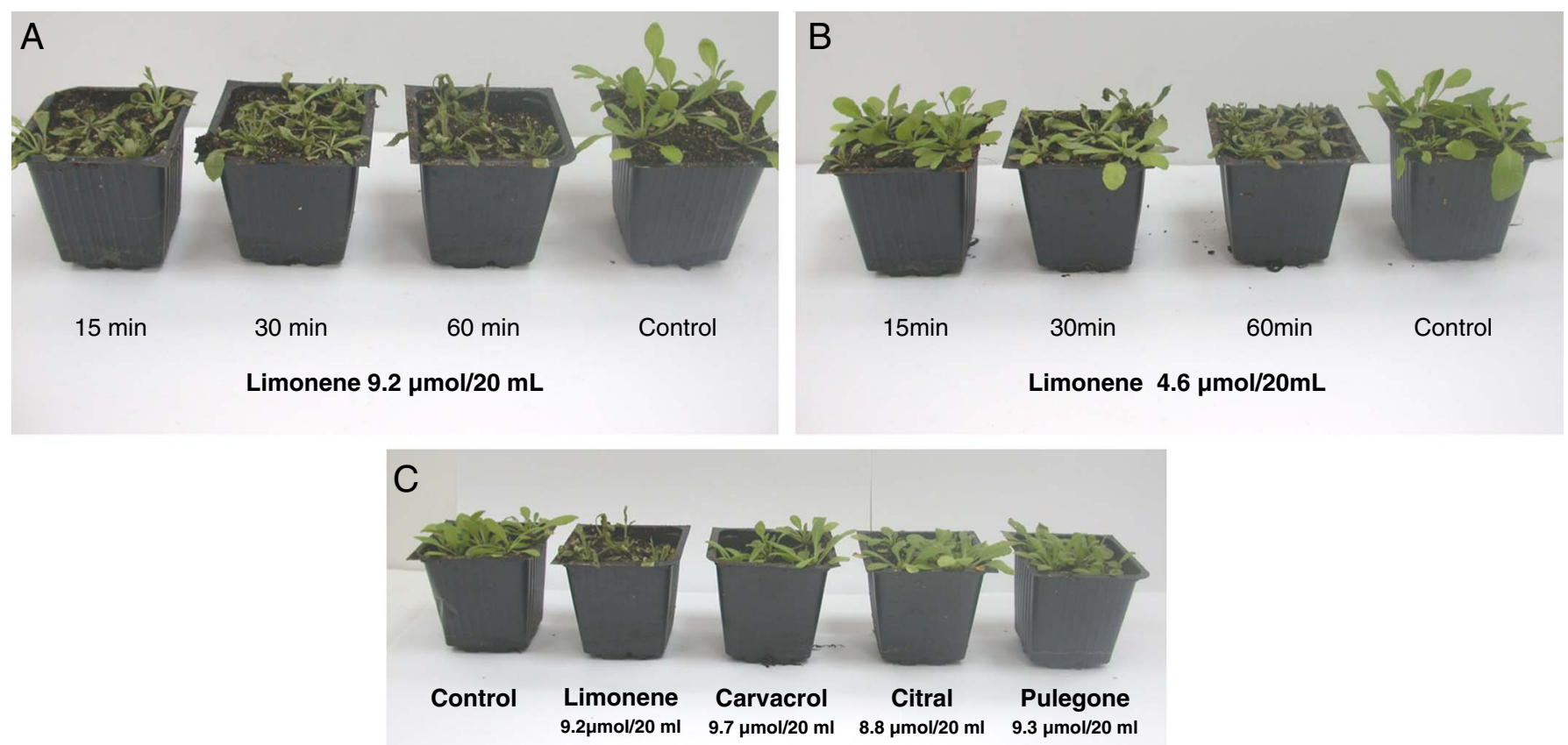

After 60 min exposure

Figure 2. Phytotoxicity of limonene, pulegone, citral, and carvacrol to Arabidopsis plants. Note: the plants were exposed to monoterpene vapors for $0,15,30$, and $60 \mathrm{~min}$, and the herbicidal potential was examined $14 \mathrm{~d}$ postexposure.

24 - Weed Science 65, January-February 2017 

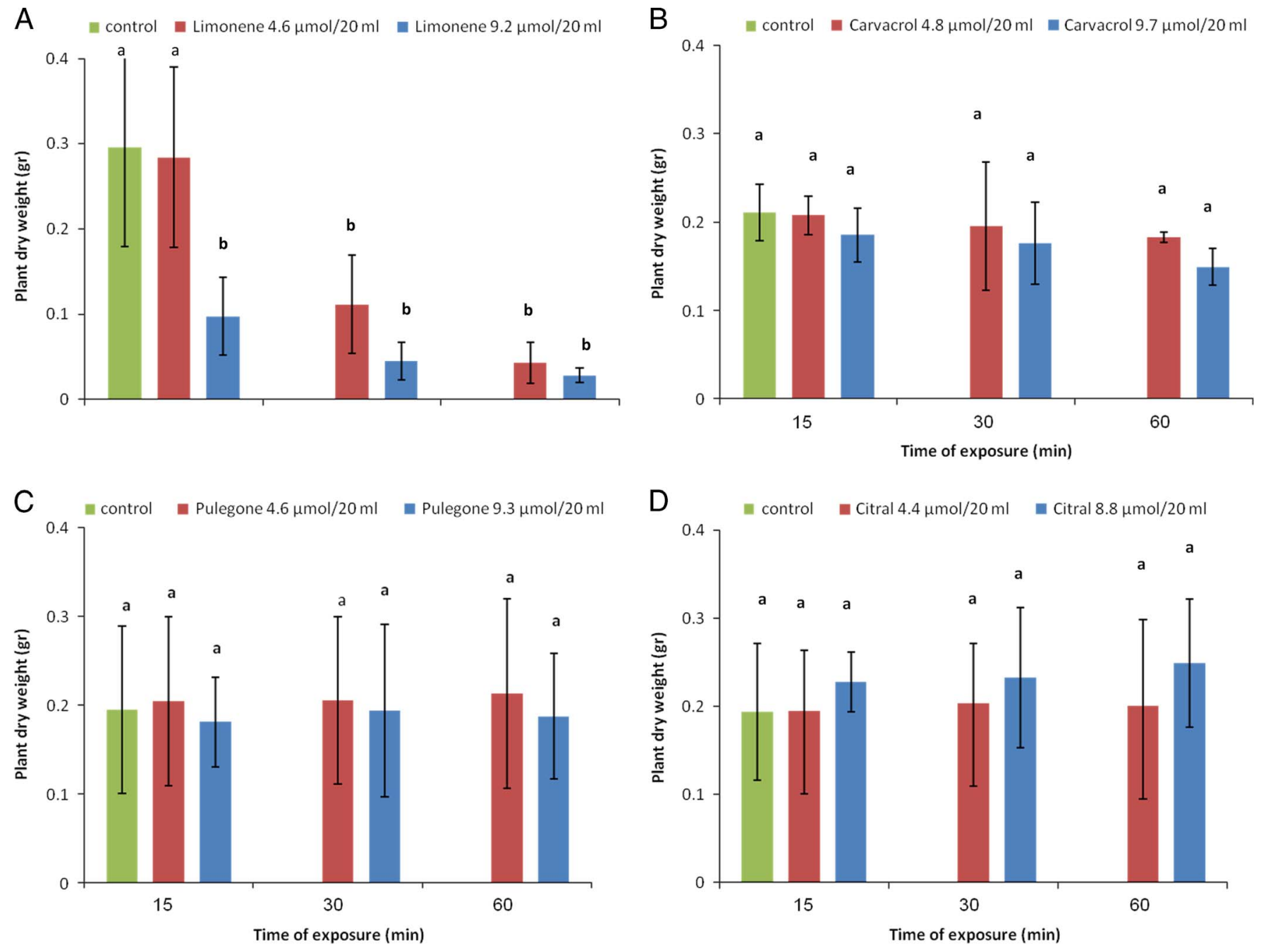

Figure 3. Effect of time and dose on fresh weight (g plant ${ }^{-1}$ ) of Arabidopsis plants exposed to limonene (A), carvacrol (B), pulegone (C), and citral (D) at vapor phase for 15, 30, and $60 \mathrm{~min}$. Lowercase letters represent treatments that were significantly different than the control as determined by ANOVA followed by Tukey's HSD post hoc test.

and analyzed by GC-mass spectrometry to measure the amounts of limonene, carvacrol, pulegone, and citral absorbed by the plants. As reflected in Table 2, a positive correlation was recorded between the residue level in the tissue and the combined compound concentration and exposure duration interaction. In other words, the higher the concentration and the longer the exposure duration were, the higher the residue level detected in the tissue. Of note was the outcome for citral and limonene. Plants that absorbed citral biochemically reduced it to nerol and geraniol; plants that absorbed limonene converted part of it to carvacrol. The levels of carvacrol and pulegone remained stable within the plants (Table 2).

Previous studies conducted by our research team (Chaimovitsh et al. 2010, 2012) shed light on the mode of action of citral. We found that microtubules were the immediate target of citral in plant and animal cells. Microtubules were disrupted in the presence of micromolar concentrations of citral, whereas F-actin and cell membrane remained intact (Chaimovitsh et al. 2010). In the present study we provide evidence that only a subset of monoterpenes disrupt microtubules. Furthermore, we confirm our previous observation (Chaimovitsh et al. 2010) that citral causes detectable damage to the plasma membrane under the same experimental conditions in which microtubule disruption was observed. Interestingly, plants exposed to citral exhibited cell swelling, inhibition of polar cell growth, zigzagged cell walls, and irregular phragmoplasts, all directly related to microtubule deformation (Grana et al. 2013a).

In the present study 10 derivatives of citral were screened. Some are known allelochemicals, such as geraniol (Martino et al. 2010; Zunino and Zygadlo 2004), citronellol (Martino et al. 2010; 

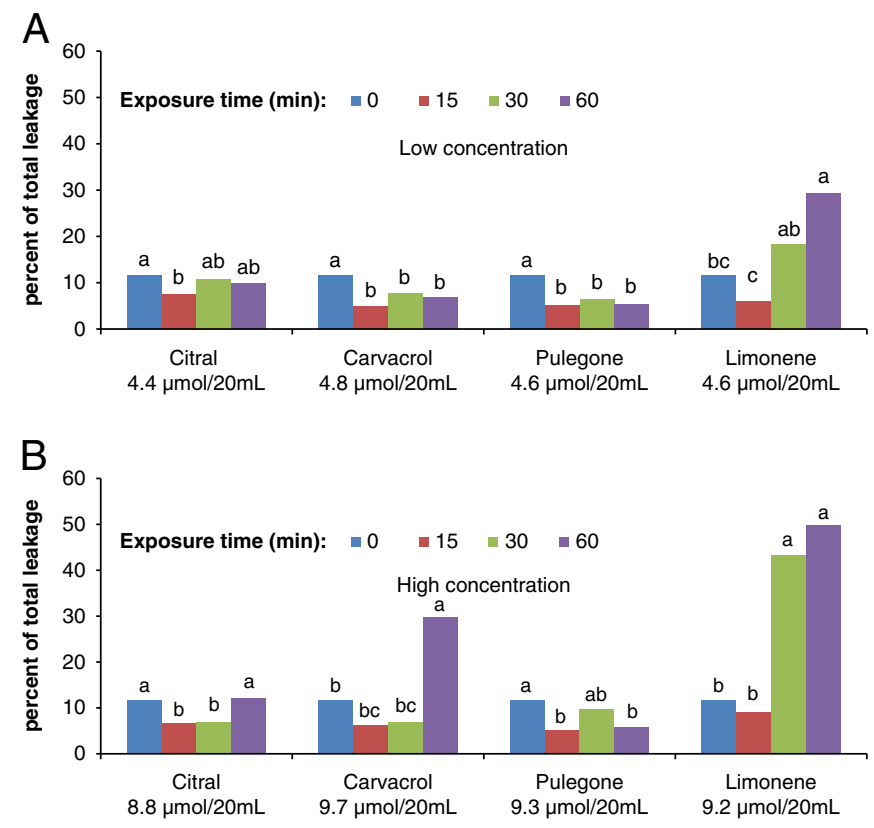

Figure 4. Effect of citral, carvacrol, pulegone, and limonene on membrane leakage in Arabidopsis plants exposed to (A) low $(0.75 \mu \mathrm{l}$ per $20 \mathrm{ml})$ and $(\mathrm{B})$ high $(1.5 \mu \mathrm{l}$ per $20 \mathrm{ml})$ dosages for 15 , 30 , and $60 \mathrm{~min}$. Lowercase letters represent treatments that were significantly different than the control as determined by ANOVA followed by Tukey's HSD post hoc test.
Singh et al. 2002), citronellal (Singh et al. 2002), and citral itself (Dudai et al. 1999; Martino et al. 2010; Sousa et al. 2010). The list also included two different enantiomers of three compounds: $(+) /(-)$-citronellal, $(+) /(-)$-citronellol, which are abundant in Java citronella (Cymbopogon winterianus Jowitt) and cymbopogon [Cymbopogon nardus (L.) W. Watson] (Kreis and Mosandl 1994b); and $(+) /(-)$-citronellic acid, which are abundant in common balm (Melissa officinalis L.) (Kreis and Mosandl 1994a). Other derivatives, such as geraniol and geranic acid, are present in sweet scented geranium (Pelargonium graveolens L'Hér. ex Aiton); nerol is abundant in cymbopogon (Kreis and Mosandl 1994b); and finally, citral dimethyl acetal is an artificial derivative of citral (Sigma-Aldrich catalog no. 7549-37-3).

Six highly active allelochemical monoterpenes were also screened. These included two enantiomers $(+) /(-)$ of carvone (Martino et al. 2010; Zunino and Zygadlo 2004), limonene (Abrahim et al. 2000; Martino et al. 2010; Singh et al. 2009b), menthone (Maffei et al. 2001; Martino et al. 2010; Mucciarelli et al. 2001), pulegone (Dudai et al. 1999, 2009;

Table 2. Monoterpene residues and their derivatives in Arabidopsis thaliana tissue.

\begin{tabular}{|c|c|c|c|c|c|c|c|c|}
\hline \multirow[b]{2}{*}{ Monoterpene } & \multirow{2}{*}{$\begin{array}{l}\text { Exposure } \\
\text { time } \\
(\mathrm{min})\end{array}$} & \multirow{2}{*}{$\begin{array}{c}\text { Quantity } \\
\text { applied }(\mu \mathrm{mol} \\
\text { per } 20 \mathrm{ml})\end{array}$} & \multicolumn{6}{|c|}{ Monoterpene and derivative residues in plant tissue $\left(\mathrm{mol} \mathrm{g} \mathrm{dry} \mathrm{weight}{ }^{-1}\right)^{1}$} \\
\hline & & & Citral & Nerol & Geraniol & Limonene & Carvacrol & Pulegone \\
\hline \multirow[t]{6}{*}{ Citral } & 15 & 4.4 & $0.0 \pm 0.0$ & $0.0 \pm 0.0$ & $0.0 \pm 0.0$ & - & - & - \\
\hline & 30 & 4.4 & $6.91 \pm 5.0$ & $0.0 \pm 0.0$ & $17.83 \pm 6.97$ & - & - & - \\
\hline & 60 & 4.4 & $45.38 \pm 21.99$ & $5.79 \pm 0.56$ & $52.15 \pm 17.6$ & - & - & - \\
\hline & 15 & 8.8 & $13.97 \pm 4.27$ & $0.0 \pm 0.0$ & $9.49 \pm 2.66$ & - & - & - \\
\hline & 30 & 8.8 & $21.26 \pm 5.67$ & $0.0 \pm 0.0$ & $40.34 \pm 3.76$ & - & - & - \\
\hline & 60 & 8.8 & $71.39 \pm 19.84$ & $8.74 \pm 0.52$ & $67.56 \pm 23.31$ & - & - & - \\
\hline \multirow[t]{6}{*}{ Limonene } & 15 & 4.6 & - & - & - & $60.04 \pm 11.4$ & $7.74 \pm 2.12$ & - \\
\hline & 30 & 4.6 & - & - & - & $512.84 \pm 92.29$ & $14.46 \pm 4.15$ & - \\
\hline & 60 & 4.6 & - & - & - & $875.76 \pm 75.7$ & $44.51 \pm 5.42$ & - \\
\hline & 15 & 9.2 & - & - & - & $264.51 \pm 12.3$ & $13.46 \pm 3.31$ & - \\
\hline & 30 & 9.2 & - & - & - & $562.39 \pm 23.36$ & $25.76 \pm 2.76$ & - \\
\hline & 60 & 9.2 & - & - & - & $937.1 \pm 62.3$ & $128.02 \pm 15.73$ & - \\
\hline \multirow[t]{6}{*}{ Carvacrol } & 15 & 4.8 & - & - & - & - & $7.26 \pm 3.05$ & - \\
\hline & 30 & 4.8 & - & - & - & - & $82.95 \pm 4.15$ & - \\
\hline & 60 & 4.8 & - & - & - & - & $106.99 \pm 17.85$ & - \\
\hline & 15 & 9.7 & - & - & - & - & $15.2 \pm 5.76$ & - \\
\hline & 30 & 9.7 & - & - & - & - & $95.06 \pm 11.08$ & - \\
\hline & 60 & 9.7 & - & - & - & - & $124.42 \pm 16.11$ & - \\
\hline \multirow[t]{6}{*}{ Pulegone } & 15 & 4.6 & - & - & - & - & - & $39.37 \pm 7.34$ \\
\hline & 30 & 4.6 & - & - & - & - & - & $112.63 \pm 33.86$ \\
\hline & 60 & 4.6 & - & - & - & - & - & $302.0 \pm 32.67$ \\
\hline & 15 & 9.3 & - & - & - & - & - & $42.88 \pm 11.14$ \\
\hline & 30 & 9.3 & - & - & - & - & - & $142.17 \pm 40.46$ \\
\hline & 60 & 9.3 & - & - & - & - & - & $312.68 \pm 32.59$ \\
\hline
\end{tabular}

Note: values are mean \pm standard deviation of five replicated Arabidopsis thaliana plants. 
Maffei et al. 2001; Mucciarelli et al. 2001), and carvacrol (Dragoeva et al. 2008; Dudai et al. 1999). It was found that in addition to citral, limonene, $(+)$-citronellal, menthone, geraniol, and (+)-carvone have the ability to disrupt plant microtubules. Based on our results, the monoterpenes examined in this work can be classified into three main groups: (1) monoterpenes with strong antimicrotubule activity, i.e., limonene and (+)-citronellal; (2) monoterpenes with moderate anti-microtubule activity, i.e., citral, geraniol, (-)-menthone, (-)-citronellal, and (+)-carvone; and (3) monoterpenes lacking antimicrotubule activity, i.e., (-)-carvone, nerol, (+)/(-)-citronellol, geranic acid, $(+) /(-)$-citronellic acid, citral dimethyl acetal, pulegone, and carvacrol.

An enantioselective activity was also recorded for isomers. The (+)-carvone and (+)-citronellal isomers were more potent than their $(-)$-carvone and (-)-citronellal counterparts in disrupting plant microtubules (Table 1), a finding which is in agreement with Altshuler et al. (2013), who showed enantioselective effects of (+)- and (-)-citronellal in animal and plant microtubules. In that work (Altshuler et al. 2013), (+)-citronellal disrupted microtubules, whereas (-)-citronellal at the same concentration did not. Interestingly, positive enantiomers of $(+)-\alpha$ pinene and $(+)-\beta$ pinene were found to have stronger antimicrobial activity than their (-) counterparts (Rivas da Silva et al. 2012). In addition, (+)-limonene and (+)-carvone had stronger activity to different bacteria and dermatophytic fungi than (-)-limonene and (-)-carvone (Aggarwal et al. 2002).

In the present study we focused on four allelochemicals_citral, limonene, carvacrol, and pulegone-which are known as seed-germination inhibitors (Dudai et al. 1999, 2009). These four monoterpenes had differential modes of action in Arabidopsis plants. Limonene was highly active, with strong microtubule- and membrane-disrupting activity. In contrast, carvacrol exhibited only membranedisrupting activity that was dependent on long exposure at high concentration. Citral exhibited microtubule- but not membrane-disrupting activity; and pulegone lacked an effect on either microtubules or cell membrane.

Limonene inflicted visible damage on the plants and demonstrated herbicidal activity. Its effect was significantly more visible than that of the three other monoterpenes. Its damage was characterized by a range of symptoms, from phytotoxicity in individual leaves to toxicity in all leaves leading to plant death. At the low dose, limonene's herbicidal activity was time dependent, while at the high dosage it was herbicidal at all exposure durations. In contrast, citral, carvacrol, and pulegone were nonherbicidal to the plants even at extended exposures to high dosages.

The effect of monoterpenes on biomass and phytotoxicity was examined using mature, 14-d-old Arabidopsis plants. A relationship between phytotoxicity and biomass reduction was observed in the case of limonene. Yet exposure of plants to the high dose of carvacrol did not show any significant biomass differences between exposed and untreated plants, and there were no clear phytotoxicity symptoms. Interestingly, citral, which is a known microtubule-disrupting agent did not incite phytotoxicity or biomass reduction, which was in contrast to its previously described effect on young seedlings (Chaimovitsh et al. 2010). This could be due to the ability of Arabidopsis to recover within hours of exposure to citral (Chaimovitsh et al. 2010). Furthermore, pulegone had no phytotoxic effect on mature Arabidopsis plants in this work. This outcome prevents clarification of its mode of action, indicating further study is needed.

We described here the influence of limonene, citral, pulegone, and carvacrol on membrane leakage in Arabidopsis plants and on the accumulation of these four monoterpenes in the plant tissue. Accumulation of limonene in the plant tissue increased dramatically with increasing dose and exposure time. The amount of limonene that was absorbed by the plants was 10 -fold higher than that of citral, 8-fold higher than that of carvacrol, and 3-fold higher than that of pulegone. This might be due to limonene's higher physical volatility. The higher concentrations that accumulated in the plants could explain the stronger antimicrotubule and antimembrane activities, hence its herbicidal potential. The observed conversion of limonene to carvacrol by Arabidopsis plants is a novel finding. Carvacrol accumulated following exposure to the high dose of limonene and showed a slight membrane leakage effect. The metabolic pathway that underlies this conversion is currently unclear. Yet the observations in this study suggest that the mode of action of carvacrol as an allelochemical is via membrane leakage at high dosages and extensive exposure duration.

Accumulated data show that growth-inhibiting effects of different monoterpenes depend on their chemical structure. Monoterpenes that contain oxygen show higher inhibitory activity toward seed germination and plant growth than hydrocarbon 
monoterpenes (Elakovich 1988; Reynolds 1987; Vaughn and Spencer 1993). Weidenhamer et al. (1993) showed a connection between inhibitory activity and water solubility of monoterpenes. Ketones were more soluble and more active than alcohols, which were more active and soluble than hydrocarbons. In addition, the bioactivity of monoterpenes seems to be inversely correlated to lipophilicity (Abrahim et al. 2000). Zunino and Zygadlo (2004) concluded that most phytotoxic monoterpenes are from the group of alcohols and phenols. The work presented here examined 17 monoterpenes for microtubule-disrupting activity, and no direct correlation was found between monoterpene structure and microtubule-disrupting activity. The most active monoterpene was limonene, a hydrocarbon that belongs to the less active group described by Weidenhamer et al. (1993). Monoterpenes from the ketone group showed differential activities toward microtubules; (+)-carvone and menthone exhibited microtubule-disrupting activity, and pulegone did not. Monoterpenes from the alcohol group also exhibited differential microtubule-disrupting activity; geraniol exhibited antimicrotubule activity, whereas citronellol and nerol did not. The monoterpenes citral and citronellal from the aldehyde group were found to exhibit microtubule-disrupting activity, but it was weaker than that of the hydrocarbon limonene.

We observed a bioconversion of citral into its derivatives nerol and geraniol in Arabidopsis plants. A similar conversion was previously described in wheat seeds and was explained as a mechanism for detoxification of citral by the seeds through reduction to less bioactive derivatives (Dudai et al. 2000b). Interestingly, while geraniol was found to have antimicrotubule activity similar to that of citral, nerol did not.

In this study, no specific effects of pulegone on microtubulin and membrane leakage in the plants were observed. Therefore, the experimental setup used here did not provide evidence for its mode of action. It is probable that higher doses of this compound are required to affect mature Arabidopsis plants.

In conclusion, the present study sheds new light on the modes of action of various monoterpenes known as allelochemicals, demonstrating that some of the monoterpenes have isomeric-specific activity and pointing out limonene as possessing high herbicidal potency. These findings could assist in designing new, natural, and ecofriendly herbicides.

\section{Acknowledgment}

The authors thank Nadav T. Nitzan for his assistance in editing and critically reviewing this article.

\section{Literature Cited}

Abad A, Kasrati A, Jamili CA, Zeroual S, M'hamed TB, SpoonerHart R, Leach D (2014) Insecticidal properties and chemical composition of essential oils of some aromatic herbs from Morocco. Nat Prod Res 28:2338-2341

Abrahim D, Braguini WL, Kelmer-Bracht AM, Ishii-Iwamoto EL (2000) Effects of four monoterpenes on germination, primary root growth, and mitochondrial respiration of maize. J Chem Ecol 26:611-624

Abrahim D, Francischini AC, Pergo EM, Kelmer-Bracht AM, Ishii-Iwamoto EL (2003) Effects of $\alpha$-pinene on the mitochondrial respiration of maize seedlings. Plant Phys Biochem 41:985-991

Aggarwal KK, Khanuja Ateeque Ahmad SPS, Santha Kumar TR, Gupta VK, Kumar S (2002). Antimicrobial activity profiles of the two enantiomers of limonene and carvone isolated from the oils of Mentha spicata and Anethum sowa. Flavour Fragr J 17:59-63

Altshuler O, Abu-Abied M, Chaimovitsh D, Shechter A, Frucht H, Dudai N, Sadot E (2013) Enantioselective effects of $(+)$ - and (-)-citronellal on animal and plant microtubules. J Nat Prod 76:1598-1604

Bassolé IHN, Juliani HR (2002) Essential oils in combination and their antimicrobial properties. Molecules 17:3989-4006

Berchielli-Robertson DL, Gilliam CH, Fare DC (1990) Competitive effects of weeds on the growth of container-grown plants. Hort Sci 25:77-79

Bernstein N, Shoresh M, Xu Y, Huang B (2010) Involvement of the plant antioxidative response in the differential growth sensitivity to salinity of leaves vs. roots during cell development. Free Radicals Biol Med 49:1161-1171

Bolte S, Talbot C, Boutte Y, Catrice O, Read ND, Satiat-JeuneMaitre B (2004) FM-dyes as experimental probes for dissecting vesicle trafficking in living plant cells. J Microscopy 214:159-173

Cantrell CL, Dayan FE, Duke SO (2012) Natural products as sources of new pesticides. J Nat Prod 75:1231-1242

Chaimovitsh D, Abu-Abied M, Belausov E, Rubin B, Dudai N, Sadot E (2010) Microtubules are an intracellular target of the plant terpene citral. Plant J 61:399-408

Chaimovitsh D, Rogovoy-Stelmakh O, Altshuler O, Belausov E, Abu-Abied M, Rubin B, Sadot E, Dudai N (2012) The relative effect of citral on mitotic microtubules in wheat roots and BY2 cells. Plant Biol 14:354-364

Chappell L, Knox G, Stamps RH (2012) Alternatives to synthetic herbicides for weed management in container nurseries. UGA Cooperative Extension Bulletin 1410. Athens, GA: University of Georgia Cooperative Extension

Christaki E, Bonos E, Giannenas I, Florou-Paneri P (2012) Aromatic plants as a source of bioactive compounds. Agriculture 2:228-243

Cox SD, Gustafson JE, Mann CM, Markham JL, Liew YC, Hartland RP, Bell HC, Warmington JR, Wyllie SG (1988) Tea tree oil causes $\mathrm{K}^{+}$leakage and inhibits respiration in Escherichia coli. Lett Appl Microbiol 26:355-358

Dayan FE, Duke SO (2014) Natural compounds as nextgeneration herbicides. Plant Physiol 166:1090-1105 
Dayan FE, Owens DK, Duke SO (2012) Rationale for a natural products approach to herbicide discovery. Pest Manag Sci 68:519-528

Di Pasqua R, Betts G, Hoskins N, Edwards M, Eroolini D, Mauriello G (2007) Membrane toxicity of antimicrobial compounds from essential oils. J Agric Food Chem 55:4863-4870

Dragoeva AP, Nanova ZD, Kalcheva VK (2008) Allelopathic activity of micropropagated Origanum vulgare ssp. hirtum and its effect on mitotic activity. Allelopathy 22:131-142

Dudai N, Chaimovitsh D, Larkov O, Fisher R, Blaicer Y, Mayer AM (2009) Allelochemicals released by leaf residues of Micromeria fruticosa in soils, their uptake and metabolism by inhibited wheat seed. Plant Soil 314:311-317

Dudai N, Larkov O, Mayer AM, Poljakoff-Mayber A, Putievsky E, Lerner HR (2000a) Metabolism of essential oils during inhibition of wheat seed germination. Pages 315-321 in Black M, Bradford KJ, Vázquez-Ramos J, eds. Seed Biology: Advances and Applications. Wallingford, UK: CABI Publishing

Dudai N, Larkov O, Putievsky E, Lerner HR, Ravid U, Lewinson E, Mayer AM (2000b) Biotransformation of constituents of essential oils by germinating wheat seed. Phytochemistry 55:375-382

Dudai N, Poljakoff-Mayber A, Mayer AM, Putievsky E, Lerner HR (1999) Essential oils as allelochemicals and their potential use as bioherbicides. J Chem Ecol 25:1079-1089

Einhellig FA (1986) Mechanisms and modes of action of allelochemicals. Pages 171-188 in Putnam AR, Tang CS, eds. The Science of Allelopathy. New York: Wiley-Interscience

Einhellig FA, Leather GR (1988) Potentials for exploiting allelopathy to enhance crop production. J Chem Ecol 14:1829-1844

Elakovich SD (1988) Terpenoids as models for new agrochemicals. Pages 250-261 in Cutler HG, ed. Biologically Active Natural Products-Potential Use in Agriculture. Washington, DC: American Chemical Society

Fischer NH (1986) The function of mono and sesquiterpenes as plant germination and growth regulators. Pages 203-218 in Putnam A, Chung-Shih T, eds. The Science of Allelopathy. New York: Wiley-Interscience

Gerwick BC and Sparks TC (2014) Natural products for pest control: an analysis of their role, value and future. Pest Manag Sci 70:1169-1185

Gorell JM, Johnson CC, Rybicki BA, Peterson EL, Richardson RJ (1998) The risk of Parkinson's disease with exposure to pesticides, farming, well water, and rural living. Neurology 50:1346-1350

Gouda NAA, Saad MMG, Abdelgaleil SAM (2016) Pre and post herbicidal activity of monoterpenes against barnyard grass (Echinochloa crus-galli). Weed Sci 64:191-200

Grana E, Diaz-Tielas C, Sanchez- Moreiras AM, Reigosa MJ (2012) Mode of action of monoterpenes in plant-plant interactions. Curr Bioactive Compounds 8:80-89

Grana E, Sotelo T, Diaz-Tielas C, Araniti F, Krasuska U, Bogatek R, Reigosa MJ, Sanchez-Morieiras AM (2013b) Citral induces auxin and ethylene-mediated malformations and arrests cell division in Arabidopsis thaliana roots. J Chem Ecol 39: 271-282

Grana E, Sotelo T, Diaz-Tielas C, Reigosa MJ, Sanchez-Moreiras AM (2013a) The phytotoxic potential of the terpenid citral on seedlings and adult plants. Weed Sci 61:469-481

Isman BB (2000) Plant essential oils for pest and disease management. Crop Protect 19:603-608
Kala PC (2015) Medicinal and aromatic plants: boon for enterprise development. J Appl Res Med Aromatic Plants 2(4): 134-139

Kettles MK, Browning SR, Prince TS, Horstman SW (1997) Triazine herbicide exposure and breast cancer incidence: an ecologic study of Kentucky counties. Environ Health Perspect 105:1222-1227

Kogevinas M, Becher H, Benn T, Bertazzi PA, Boffetta P, Buenode-Mesquita HB, Coggon D, Colin D, Flesch-Janys D, Fingerhut M, Green L, Kauppinen T, Littorin M, Lynge E, Mathews JD, Neuberger M, Pearce N, Saracci R (1997) Cancer mortality in workers exposed to phenoxy herbicides, chlorophenols, and dioxins. An expanded and updated international cohort study. Am J Epidemiol 145:1061-1075

Koitabashi R, Suzuki T, Kawazu T, Sakai A, Kuroiwa H, Kuroiwa T (1997) 1,8-Cineole inhibits root growth and DNA synthesis in the root apical meristem of Brassica campestris L. J Plant Res 110:1-6

Kost B, Spielhofer P, Chua NH (1998) A GFP-mouse talin fusion protein labels plant actin filaments in vivo and visualizes the actin cytoskeleton in growing pollen tubes. Plant J 16:393-401

Kreis P, Mosandl A (1994a) Chiral compounds of essential oils. Part XVI. Simultaneous stereoanalysis of cymbopogon oil constituents. Flav Frag J 9:249-256

Kreis P, Mosandl A (1994b) Chiral compounds of essential oils. Part XVII. Simultaneous stereoanalysis of cymbopogon oil constituents. Flav Frag J 9:257-260

Lambert RJW, Skandamis PN, Coote PJ, Nychas G-JE (2001) A study of the minimum inhibitory concentration and mode of action of oregano essential oil, thymol and carvacrol. J Appl Microbiol 91:453-462

Lewinsohn E, Dudai N, Tadmor Y, Katzir I, Ravid U, Putievsky E, Joel DM (1998) Histochemical localization of citral accumulation in lemongrass leaves (Cymbopogon citratus (DC.) Stapf., Poaceae). Ann Bot 81:35-39

Maffei M, Camusso W, Sacco S (2001) Effect of Mentha × piperita essential oil and monoterpenes on cucumber root membrane potential. Phytochemistry 58:703-707

Martino LD, Mancini E, Rolim de Almeida LF, De-Feo V (2010) The antigerminative activity of twenty-seven monoterpenes. Molecules 15:6630-6637

Mucciarelli M, Camusso W, Bertea CM, Bossi S, Maffei M (2001) Effect of (+) pulegone and other oil components of Mentha $\times$ Piperita on cucumber respiration. Phytochemistry 57:91-98

Narwal SS (1999) Allelopathy in weed management. Pages 203-254 in Narwal SS, ed. Allelopathy Update: Basic and Applied Aspects. Volume 2. Enfield, NH: Science Publisher

Pimentel D, Zuniga R, Morrison D (2005) Update on the environmental and economic costs associated with alieninvasive species in the United States. Ecol Econ 52:273-288

Reynolds T (1987) Comparative effect of alicyclic compounds and quinones on inhibition of lettuce fruit germination. Ann Bot 60:215-223

Rivas da Silva AC, Monteiro Lopes P, Barros de Azevedo MM, Machado Costa DC, Sales Alviano C, Sales Alviano D (2012) Biological activities of $\alpha$-pinene and $\beta$-pinene enantiomers. Molecules 17:6305-6316

Seiber JN, Coats J, Duke SO and Gross AD (2014) Biopesticides: state of the art and future opportunities. J Agri Food Chem 62:11613-11619

Sikkema J, De-Bont JAM, Poolman B (1995) Mechanisms of membrane toxicity of hydrocarbons. Microbiol Rev 59:201-222 
Singh HP, Batish DR, Kaur S, Arora K, Kohli RK (2009a) $\alpha$-Pinene inhibits growth and induces oxidative stress in roots. Ann Bot 98:1261-1269

Singh HP, Batish DR, Kaur S, Ramezani H, Kohli RK (2002) Comparative phytotoxicity of four monoterpenes against Cassia occidentalis. Ann Appl Biol 141:111-116

Singh HP, Kaur S, Mittal S, Batish DR, Kohli RK (2009b) Essential oil of Artemisia scoparia inhibits plant growth by generating reactive oxygen species and causing oxidative damage. J Chem Ecol 35:154-162

Sousa SM, Silva PS, Viccini LF (2010) Cytogenotoxicity of Cymbopogon citratus (DC) Stapf (lemon grass) aqueous extracts in vegetal test systems. Ann Acad Bras Cienc 82:305-311

Ueda K, Matsuyama T, Hashimmoto T (1999) Visualization of microtubules in living cells of transgenic Arabidopsis thaliana. Protoplasma 206:201-206
Vaughn SF and Spencer GF (1993) Volatile monoterpenes as potential parent structures for new herbicides. Weed Sci 41:114-119

Weidenhamer JD, Macias FA, Fischer NH, Williamson GB (1993) Just how insoluble are monoterpenes? J Chem Ecol 19:1799-1803

Weidenhamer JD, Menelaou M, Macias FA, Fisher NH, Richardson DR, Williamson B (1994) Allelopathic potential of menthofuran monoterpenes from Calamintha ashei. J Chem Ecol 20:3345-3359

Zunino MP, Zygadlo JA (2004) Effect of monoterpenes on lipid oxidation in maize. Planta 219:303-309

Received March 13, 2016, and approved August 25, 2016.

Associate Editor for this paper: Franck E. Dayan, Colorado State University. 